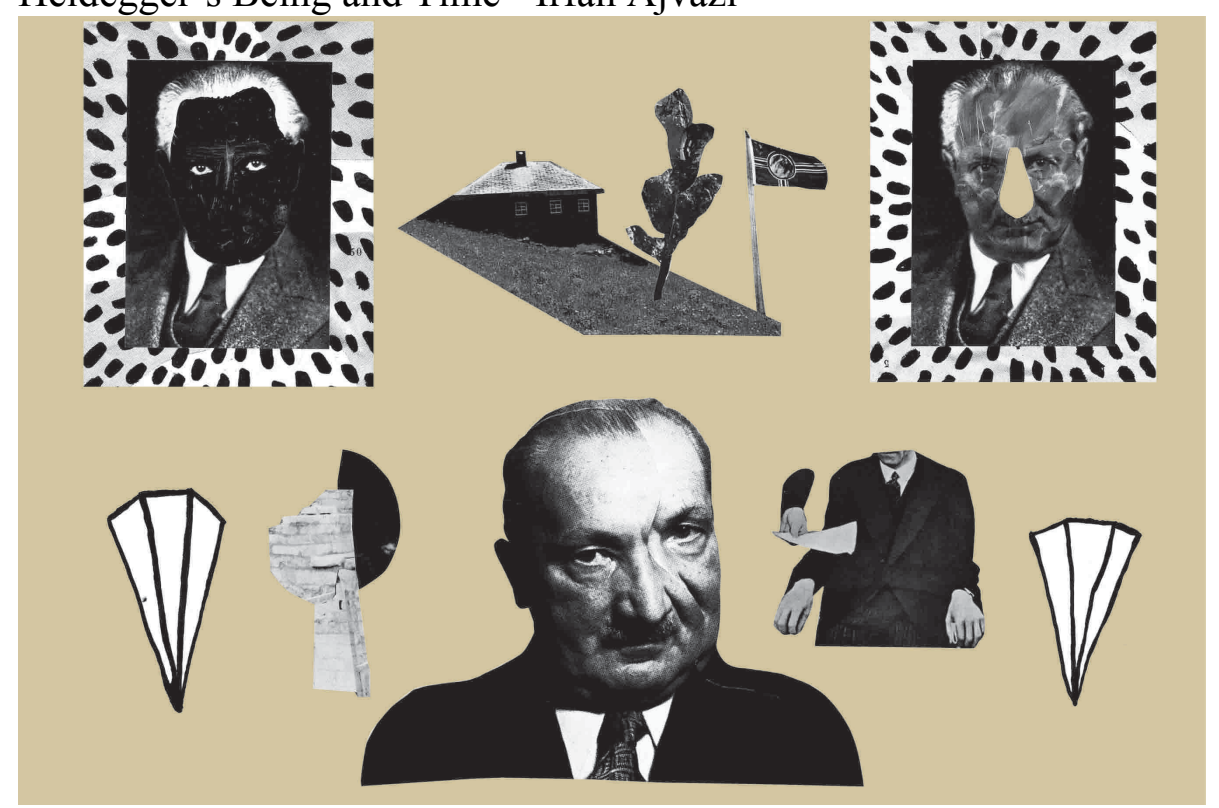

Heidegger's concept of time too is not limited to watch or calendar rather it is a kind of temporality that can be experienced in any single moment.

It is with this audacious thought, Heidegger questions the credibility of history of philosophy that till then have limited the objects to their mere presence, thus ignoring the other side, which as per him, completes the entire reality. Modern technology too has reduced the objects merely to their presence by focusing only on the utility functions.

According to Heidegger, concept of time is only relevant to beings and not to any inanimate objects. As indicated by his theory, humans are the only entities that exist in the world, rest of the objects do not have access of the surrounding world. Dasein is the German term that has not been translated, which signifies 'human existence' or the 'state of being' in his entire work. The term cannot be replaced with 'human being' since the word is already saturated with lots of conventional theories and prejudices.

According to Heidegger, concept of time is only relevant to beings and not to any inanimate objects. As indicated by his theory, humans are the only entities that exist in the world, rest of the objects do not have access of the surrounding world. Dasein is the German term that has not been translated, which signifies 'human existence' or the 'state of being' in his entire work. The term cannot be replaced with 'human being' since the word is already saturated with lots of conventional theories and prejudices. For instance, human beings are considered higher mammals with rational abilities, creatures that build up structures with the help of tools, advanced African Apes, curious beings that play around with technologies or mortal bodies encasing immortal souls. Heidegger wanted to minus these theories completely, so he created Dasein, which can only be looked with a single beam of philosophical light and character of which is only temporality.

This thought process of Heidegger's echoes Critique of Pure Reason, the famous 18th century work by Immanuel Kant. As stated by Kant in \"first critique,|" philosophically, discussing things as they are have no bottom line. Limitations of humans with respect to their experiences are one of the major hurdles in defining the actuality. It is beyond the understanding of humans to comprehend something to its completeness. For example, humans cannot comprehend whether space and time can exist independent with respect to themselves (humans). However, they can assert that both are necessary for human survival. It is next to impossible for humans to decipher as to what or how it is to feel outside human experience. The dimension is still unexplored and unfathomable for human beings.

His ideas are simple but the Heideggerian terminologies make this work slightly difficult to read. Still the book has its own charm.

He strips bare the entire concept of being and presents its existential analysis as the purpose of ontology to form an axiomatic basis for our existence in terms of Being and Being-in-the-World. The second aspect here is obviously Time, or temporality and its nature and relation to Being, again ontologically. If you don't have a firm grasp on the difference between ontological and ontical, the former the philosophy and theory of Being at its most general, the 
latter the study of the 'thing-hood' of individual beings and in a sense the theory of knowledge and cognitive process. These are necessarily reductive explanations, and Heidegger has his own system of language and classification that underlies the arguments of his overarching thesis, which he frequently restates and updates as he adds more and more to the arguments and elucidation, which is helpful.

Heidegger main goal is undercut the ontology that generates either/ors, the kind of ontology found in Plato's forms, Aristotles' primary substances, the Creator of Christian belief, Descartes' rex extensa and res cognitans, Kant's noumena, the physical stuff presupposed by scientific naturalism. Frede calls this $\backslash$ "substance ontology $\mid$ ": the view that what is ultimately real is that which underlies properties - what stands under and remains continuously present throughout all change. Heidegger challenges the idea that the real world must be thought of in terms of substance at all. In Being and Time, Heidegger quickly notes that ontology as such, the question of being, ।"remains itself naïve and opaque $\backslash$ if it fails to inquire first into the meaning of being (31).

In other words, since what things are are only intelligible to us insofar as they prove themselves to be determinate or relevant to us, we need a fundamental ontology that clarifies the meaning of things in general. And since our ।"being-therel" (Dasein) is \"the horizon in which something like being in general becomes intelligible,।" fundamental ontology must clarify \"an understanding which itself belongs to the constitution of the entity called Dasein $\backslash "$ (274). The question of being, thus, is reformulated as a question about the condition for the accessibility of things. As Guigon, the author of Cambridge's companion to reading Heidegger, argues: \"In Heidegger's view, there is no pure, external vantage point to which we can retreat in order to get a disinterested, presupposition-less angle on things \" (6). As Taylor shows in \"Engaged Agency,।" it is only because we are always in a familiar life-world, that we have some pre-understanding of what things are all about. It is our being as participants in a shared practical world that first gives us a window onto ourselves and reality.

Heidegger successfully redirected my attention onto the importance and primacy of Ontology (phenomenology, het., etc.), and the Cognitive Sciences as worth life pursuits. He suffered from the same loss of resolve with the classic realm of philosophers when it came to the difficulty of defining the focus' of our attention: what is Being? What does it mean to be a being in a world surrounded by, supposedly, individual beings?

Heidegger's plan in Sein und Zeit is twofold. First, he wants to destroy the whole philosophical tradition (basically Aristotle, Descartes and Kant). Second, he wants to ask the original, pure question of Being. Strangely, he starts with the latter, only to plan to write three volumes on the first task (which he never did). So, we end up with a preliminary analysis of Being.

The problem is, this world of average everydayness is a flight. We exist as 'men', in the sense that we are occupied with talking, curiosity and ambiguity in our everyday lives. We are never truly aware of our own existence, we just keep on living like we always have, which originated when we were thrown into the world. For Heidegger, this mode of living is an escape route from the fear of death which our existence invokes. When we, as beings, occupy ourselves with our own Being, we are (literally) designing our own lives, in the sense that we are consciously exploring all possibilities for us to exist.

First, this creates a future for us, a state to be which we are not - yet. But a division between current and future state immeditaly leads to a perception of a past, something we were but are not anymore. This is a very intuitive and immediate approach to the question: What is time? Heidegger views temporality as the fundamental meaning of Being for human existence - time is the horizon which gives all our moments of existence a particular meaning: it offers us everydayness (now), historicity (past) and real time (intertemporality - time in the world of things). By the way, it is intertemporality which is the origin of the notion of time which is current in traditional philosophy, science and common sense.

Second, our exploring of possibilities to be includes the possibility to not-be - the option to not exist. This literally is nothingness, which frightens us so much that we fall into our existence as 'man'. Although Heidegger is not occupied with ethics - at all - a gloomy mood seems to permeate all of Sein und Zeit, especially the second part where temporality and death kick in. For Heidegger, human existence is running ahead (anticipating) death. It is his claim that an authentic life, a life designed by oneself, is a life which faces up to this fear of death, which seems to advocate a life lived in continuous fear of death - consciously! Heidegger implicitly seems to suggest us what living a 'good life' consists of: overcoming our fallen status as 'men' of communities, embracing our fears of death, and realize the possibilities our consciences dictate us.

Of course, there is much more to be said about Heidegger's magnum opus, and many parts are not clear - at all - and have led to interpretation after interpretation of professional scholars. The above are some of the big themes and 
flavors running through Sein und Zeit. The most important thing to remember when reading the book is what Heidegger is doing and what he isn't doing.

Having been a student of Edmun Husserl, the father of phenomenology, he takes the phenomenological method - the study of phenomena as they appear to our consciousness, in their pure form - and applies it to human existence in its everday life. The comparison between Husserl and Heidegger is telling in itself. Husserl believed that to find the foundation of all existence (Being, if one wills) we have to observe how beings appear to us in our life-world of everyday experience; we then have to describe these phenomena in their purity, apart from any physical, psychological, or even mathematical concepts. This leads us to the discovery that in our consciousness there lie certain transcendental structures (i.e. independent of the world of reality) which are the necessary conditions for any experience, let alone knowledge to be possible.

Heidegger takes over the main aim of this method - to find the foundation of beings (Being) - but instead of the inward turn to consciousness, he seeks to fidn the meaning of every existing thing in human existence. We exist, as beings, in the world, and it is this reciprocal structure which has to be analyzed and broken down into moments of human existence (world, being-in, there). There is an important difference here - apart from the domain the phenomenological method was applied to in both thinkers - which is this. For Heidegger, the phenomenogical analysis of human existence and its resultant, found existential structures, is only a first step to the further question of Being. Husserl thought he found the foundation of existence in his transcendental phenomenology (pure Ideas as fundamental structures/necessary conditions) and that's basically it. Heidegger recognizes human existence is only one mode of existence; an analysis of human existence - its structures, its meaning, its moments - is only a preliminary stage to a more fundamental question: What is Being?

Heidegger analyzes human existence in its appearances in everyday existence; interprets these phenomena in terms of 'caring' (as in caring for what happens, what goes on, sort of like attention and health care in one); and offers us a fundamental ontology of human existence (i.e. its elemental structures).

The problem with traditional philosophy is that it is solely occupied with being in the real world, not Being, and Aristotle's categories - the ontological underpinnings of basically the whole tradition - deal with things in the world, not with human existence. This means that Heidegger has to found a whole new science, with a whole new apparatus of concepts and definitions. Or rather: he has to invent a whole new language with which to describe all the phenomena in this new field of knowledge.

Like a true German, he uses ancient terms in new senses, he invents new words and basically let's go of any constraints of logic or the sciences. Interesting fields? Perhaps. Might be even useful. But not appropriate to understand human being and Being as such. So, out goes all rules, structure, and convention, and with them, accessibility and comprehensibility. To master Heidegger, one has to learn his language. Apart from this, the book was rather written in a rush, to finish it before his academic promotion - which doesn't help either.

In sum, the reader has to learn a new language, look at old problems through a new lens; wrestle through 600 pages of abstract German prose which seems to drone on and on and on, and which repeat itself almost endlessly; and all the while keeping track of the minute progress which Heidegger makes throughout the book. The book reads like a plant, growing as time passes by. It is a beautiful experience, that's for sure, but after the third re-interpretation of the same old phenomena, one get's the feeling that this excursion will never end. And this is exactly Heidegger's point: first the everyday world has to be broken down and interpreted to reveal the fundamental structures of human existence. Then the discovery of 'care' as basic mode of human existence forces us to re[interpret all these existential structures. When we then stumble unto temporality (as the meaning of human existence, i.e. as the totality of possible modes of existence of a human being - get it?) and the whole re-interpretation process starts over again: now all fundamental structures have to be interpreted in the light of temporality. And then, when all this is over, Heidegger anounces that perhaps temporality - as 'original time' the meaning of being - perhaps forms the horizon of Being - requiring a fresh start. Luckily for us, he never finished this third part of the first volume; sadly, the three parts of the second volume - the destruction of the whole philosophical tradition - was never finished either. So we end up with an obscure, almost incomprehensible, unfinished work.

\section{BEING AND BECOMING}

What becomes is not yet. What is need no longer become. What $\backslash$ "is $\backslash$ ", the being, has left all becoming behind it if indeed it ever became or could become. What $\backslash$ "is $\backslash "$ in the authentic sense also resists every onsurge of becoming. 


\section{BEING AND APPEARANCE}

Appearing [is] self-manifestation, self-representation, standing-there, presence.

The realm of emerging and abiding is intrinsically at the same time a shining appearing. There are three modes of [appearing or] \"Schein $\backslash "$ :

1. Radiance and glow;

2. Appearing, coming to light; and

3. Mere appearance or semblance.

...for the Greeks, standing-in-itself was nothing other than standing-there, standing-in-the-light. Being means appearing. Appearing is not something subsequent that sometimes happens to being. Appearing is the very essence of being.

\section{Unconcealment}

The essence of being is physis. Appearing is the power that emerges. Appearing makes manifest... being, appearing, causes to emerge from concealment. Since the being as such is, it places itself in and stands in unconcealment, aletheia...The being is true insofar as it is. The true as such is being. This means: The power that manifests itself stands in unconcealment. In showing itself, the unconcealed as such comes to stand. Truth as un-concealment is not an appendage to being.

Truth is inherent in the essence of being. To be a being - this comprises to come to light, to appear on the scene, to take one's/its place, to produce something. Non-being, on the other hand, means: to withdraw from appearing, from presence.

Beings display themselves as the momentary and close-at-hand. In appearing it gives itself an aspect, dokei. Doxa means:

1. Regard as glory;

2. Regard as sheer vision that offers something;

3. Regard as mere looking-so: appearance as mere semblance;

4. View that a man forms, opinion.

Doxa means aspect, regard...to place in the light and thus endow with permanence, being. [I show myself, appear, enter into the light. Here the emphasis is on sight and aspect, the regard in which a man stands...esteem.] For the Greeks glory was not something additional which one might or might not obtain; it was the mode of the highest being...appearing belonged to being, or more precisely...the essence of being lay partly in appearing.

Because being, physis, consists in appearing, in an offering of appearance and views, it stands, essentially and hence necessarily and permanently, in the possibility of an appearance which precisely covers over and conceals what the being in truth, i.e., in unconcealment, is. This regard in which the being now comes to stand is Schein in the sense of semblance.

\section{l"The Tragedy of Appearancel"}

It was in the Sophists and in Plato that appearance was declared to be mere appearance and thus degraded. At the same time, being, as idea, was exalted to a suprasensory realm.

A chasm... was created between the merely apparent being here below and real being somewhere on high. In that chasm, Christianity settled down, at the same time reinterpreting the lower as the created and the higher as the creator. 
[It is] necessary to secure the priority of truth as unconcealment, of discovery over occultation and distortion.

\section{BEING AND THINKING}

Thinking sets itself off against being in such a way that being is placed before it and consequently stands opposed to it as an object...being takes on its entire interpretation from thinking.

In the seemingly unimportant distinction between being and thinking, we must discern the fundamental position of the Western spirit, against which our central attack is directed.

Thinking refers to the future as well as the past, but also to the present.

Thinking brings something before us, represents it. This representation always starts from ourselves, it is a free act, but not an arbitrary one, for it is bound by the fact that in representing we think of what is represented and think it through by dissecting it, by taking it apart and putting it together again. But in thinking we not only place something before ourselves, we not only dismember it for the sake of dismembering, but, reflecting, we pursue the thing represented. We do not simply accept it as it happens to fall to us; no, we undertake, as we say, to get behind the thing. We find out how it stands with the thing in general. We get an idea of it, we seek the universal.

\section{Separation of Logos and Physis}

How did the separation between logos and physis come about? How did the logos (the 'logical') become the essence of thinking? [Hegel: 'the logical is the absolute form of truth and, what is more, it is also the pure truth itself.] How did this logos in the sense of reason and understanding achieve domination over being in the beginning of Greek philosophy?

Being in the sense of physis is the power that emerges. As contrasted with becoming, it is permanence, permanent presence. Contrasted with appearance, it is appearing, manifest presence.

What else can logos mean but statement, discourse, word?

Heraclitus' doctrine of the logos was regarded as the forerunner of the logos that figures in the New Testament...the logos is Christ...the God-man.

Noein is understood as thinking, an activity of the subject. The thinking of the subject determines what being is. Being is nothing other than the object of thinking, that which is thought. But since thinking remains a subjective activity, and since thinking and being are supposed to be the same according to Parmenides, everything becomes subjective. Nothing is in itself. But such a doctrine, we are told, is found in Kant and the German idealists. Essentially Parmenides anticipated their teachings.

According to Heraclitus what man is is first manifested (edeixe, shows itself) in polemos, in the irruption of being itself. For philosophy what man is is not written somewhere in heaven. Only where being discloses itself in questioning does history happen and with it the being of man, by virtue of which he ventures to set himself apart from the being as such and contend with it.

Only as a questioning historical being does man come to himself; only as such is he a self. Man's selfhood means this: he must transform the being that discloses itself to him into history and bring himself to stand in it. Selfhood does not mean that he is primarily an 'ego' and an individual. This is no more than he is a 'we', a community.

The initial separation between logos and physis led to the secession of the logos, which became the starting point for the domination of reason [i.e., in the contest between rationalism and irrationalism].

This secession of the logos which started logos on its way to becoming a court of justice over being occurred in Greek philosophy itself. Indeed, it brought about the end of Greek philosophy.

In the end the word idea, eidon, 'idea', came to the fore as the decisive and predominant name for being (physis). Since then the interpretation of being as idea has dominated all Western thinking throughout the history of its transformations down to the present day. This origin also explains why, in the great and definitive culmination of the first period of Western thinking, in the system of Hegel, the reality of the real, being in the absolute sense, is 
conceived as 'idea' and expressly so called.

In our first introductory characterisation of the Greek experience of being, we listed idea, eidos among other names for it... In reading the philosophy of Hegel or of any other modern thinker, or in studying medieval Scholasticism, we frequently run across the use of the word 'idea' for being.

The word idea means that which is seen in the visible, the aspect it offers. What is offered is the appearance, eidos, of what confronts us. The appearance of a thing is that wherein, as we say, it presents, introduces itself to us, places itself before us and as such stands before us, that wherein and as such it is present, i.e., in the Greek sense, is.

This standing is the stability of that which has emerged from out of itself, of physis. But from the standpoint of man this standing-there of the stable and permanent is at the same time the surface of what is present through itself, the apprehensible. In the appearance, the present, the being, presents its what and how. It is apprehended and taken, it is in the possession of an acceptance, its property, it is the accessible presence of the present: ousia. Thus ousia can signify both: the presence of something present; and this present thing in the what of its appearance.

Herein is concealed the source of the subsequent distinction between existentia and essentia.

Thus the idea constitutes the being. But here idea and eidos are used in an extended sense, not only for that which is visible to the physical eye; but for everything that can be perceived. What a being is lies in its appearance, but the appearance presents (makes present) the what.

The crux of the matter is not that physis should have been characterised as idea; but that the idea should have become the sole and decisive interpretation of being. [The idea, as the appearance of the being, came to constitute its what.]

Physis is the emerging power, the standing-there-in-itself, stability. Idea, appearance as what is seen, is a determination of the stable insofar and only insofar as it encounters vision. But physis as emerging power is by the same token an appearing. Except that the appearing is ambiguous...Appearing means, first: that which gathers itself, which brings-itself-to-stand in its togetherness and so stands. But second it means: that which, already standingthere, presents a front, a surface, offers an appearance to be looked at.

\section{Being and Apprehension}

But does not Parmenides' maxim say: being and apprehension - that which is seen and the act of seeing - belong together? Yet, to be sure, the thing seen belongs to seeing, but from this it does not follow that being-seen alone determines, or could determine, the presence of the thing seen. Parmenides' maxim does not say that being should be understood on the basis of apprehension, i.e., as something merely apprehended; it says rather that apprehension should be considered for the sake of being. Apprehension should so disclose the being as to put it back in its being; it should consider that the being presents itself and as what. But in the interpretation of being as idea, not only is an essential consequence twisted into an essence, but the falsification is once again misinterpreted. And this too occurred in the course of Greek experience and interpretation.

\section{Being as Idea}

As soon as the essence of being resides in whatness (idea), whatness, as the being of the being, becomes that which is most beingful in a being. It becomes the actual being, ontos on. Being as idea is exalted, it becomes true being, while being itself previously dominant, is degraded to what Plato calls me on, what really should not be and really is not, because in the realisation it always deforms the idea, the pure appearance, by incorporating it in matter. The idea now becomes a paradeigma, a model. At the same time, the idea necessarily becomes an ideal. The copy actually 'is' not; it merely partakes of being, it is a methexis. The chorismos, the cleft, has opened between the idea as what really is, the prototype and archetype, and what actually is not, the copy and image.

From the standpoint of the idea, appearing now takes on a new meaning. What appears - the phenomenon - no longer physis, the emerging power, nor is it the self-manifestation of the appearance; no, appearing is now the emergence of the copy. Since the copy never equals its prototype, what appears is mere appearance, actually an illusion, a deficiency. Now the on becomes distinct from the phenomenon. And this development brings with it still another vital consequence. Because the actual repository of being is the idea and this is the prototype, all disclosure of being must aim at assimilation to the model, accommodation to idea. The truth of physis, aletheia as the 
unconcealment that is the essence of the emerging power, now becomes homoiosis and mimesis, assimilation and accommodation, orientation by..., it becomes a correctness of vision, of apprehension as representation.

\section{Correctness and Un-distortion}

The being is disclosed in the logos as gathering. This is first effected in language. Consequently the logos becomes the essential determinant of discourse. Language - what is uttered and said and can be said again - is the custodian of the disclosed being. What has once been said can be repeated and passed on. The truth preserved in it spreads, and in the process the being originally gathered and disclosed is not each time experienced for itself. In the transmission the truth detaches itself as it were from the being.

Logos in the sense of discourse and utterance becomes the realm and the scene of decision concerning the truth, i.e., originally, the unconcealment of the being and hence its being. Initially the logos as gathering is the event of unconcealment, grounded in unconcealment and serving it. Now logos as statement becomes the abode of truth in the sense of correctness. And this process culminates in Aristotle's proposition to the effect that logos as statement is that which can be true or false. Truth that was originally unconcealment, a happening of the dominant being itself, governed by gathering, now becomes an attribute of the logos. In becoming an attribute of statement, the truth not only shifts its abode; it changes its essence as well. From the standpoint of statement, the truth is achieved if discourse adheres to what it speaks of; if the statement follows the being. The truth becomes the correctness of the $\log$ os.

Physis becomes idea, truth becomes correctness. Logos becomes statement, the locus of truth as correctness, the source of the categories, the fundamental principle in regard to the possibilities of being. 'Idea' and 'category' become the two terms that dominate Western thought, action, and evaluation, indeed all Western being-there.

From the standpoint both of the idea and of statement, the original essence of truth, aletheia (unconcealment) has changed to correctness. For unconcealment is that heart and core, i.e., the dominant relation between physis and logos in the original sense. The very essence of dominance is emerging-into-unconcealment. But apprehension and gathering govern the opening up of unconcealment for the being. The transformation of physis and logos into idea and statement has its inner ground in a transformation of the being of truth from concealment to correctness.

Unconcealment [is] the space created for the appearing of the being.

Ever since idea and category became sovereign, philosophers have tormented themselves in vain, seeking by every possible and impossible stratagem to explain the relation between statement (thinking) and being - in vain, because they never again carried the question of being back to its native ground and soil, thence to unfold it.

The Greek for 'to distort something' is pseudesthai. Thus the struggle for the unconcealment of the being, aletheia, became a struggle against pseudos, distortion and perversion. But it is in the very nature of struggle that whether a contestant wins or loses, he becomes dependent on his adversary. Because the battle against untruth is a battle against the pseudos, the battle for the truth becomes - from the standpoint of the combated pseudos - a battle for the a-pseudos, the undistorted, unperverted.

This transformation of unconcealment by way of distortion to undistortion and thence to correctness must be seen in one with the transformation of physis to idea, of logos as gathering to logos as statement.

\section{Permanence}

Being signifies permanent presence, already-thereness. What actually has being is accordingly what always is, aei on.

Apprehension, noein, is taken over by the logos in the sense of statement. Thus it becomes the apprehension which, in determining something as something, thinks-through what it encounters, dianoeisthai. This discursive thinkingthrough defines the understanding in the sense of evaluating representation. Apprehension becomes understanding.

Ousia (permanent presence) now began to be interpreted as substantia. Ousia has become the decisive term for being. 
actually seen, the idea which, as the ontos on, is again the permanent and enduring as opposed to changing appearance. But becoming and appearance are not determined only on the basis of ousia, for ousia in turn has been essentially defined by its relation to logos, discursive judgment, dianoia. Accordingly, becoming and appearance are defined in the perspective of thought.

From the standpoint of evaluating thought, which always starts from something permanent, becoming appears as impermanence. In the realm of the already-there, impermanence is manifested primarily as not remaining in the same place. Becoming is seem as change of place, transposition. All becoming is regarded as motion, and the decisive aspect of motion is change of place.

\section{BEING AND THE OUGHT:}

Plato conceived of being as idea. The idea was a prototype and as such set the measure. What seems more plausible than to take Plato's ideas in the sense of values and to interpret the being of the Being from the standpoint of value? [Thus, History came to be regarded as a realisation of values.]

Insofar as the ideas constitute being, ousia, the idea tou agathou, the supreme idea, stands, beyond being. Thus being itself, not as such but as idea, comes into opposition to something other, on which it, being, is dependent. The supreme idea has become the model of the models.

Being itself, interpreted as idea, brings with it a relation to the prototypical, the exemplary, the ought. As being itself becomes fixated as idea, it strives to make good the resulting degradation of being. But by now this is possible only if something is set above being, something that being never is yet but always ought to be.

The ought is opposed to being as soon as being defines itself as idea.

In statement the 'is' serves as a copula, as a 'little word of relation' (Kant). But because statement, logos as kategoria, has become a court of judgment over being, it defines being on the basis of its own 'is', the 'is' of statement.

\section{TIME:}

When ultimately ousia, meaning permanent presence, became the basic concept of time, what was the unconcealed foundation of permanence and presence if not time?

Time had to be taken as something somehow present, ousia tis. Consequently time was considered from the standpoint of the 'now', the actual moment. The past is the 'no-longer-now', the future is the 'not-yet-now'. Being in the sense of already-thereness (presence) became the perspective for the determination of time. But time was not the perspective specially chosen for the interpretation of being.

The essential is not number; the essential is the right time, i.e., the right moment, and the right perseverance.

Martin Heidegger's (1889 -- 1976) \"Being and Timel" (1927), together with Ludwig Wittgenstein's \"Philosophical Investigations $\backslash "$ is one of the seminal philosophical works of the Twentieth Century. The work still remains difficult, obscure, and highly controversial. The book, and its author, provoke wildly varying responses. This translation, by Macquarrie and Robinson dates from 1962 and appeared in paperback only in 2008 with a useful introduction by philosopher Taylor Carman. Another translation, by Joan Stambaugh, appeared some years ago; but the Macquarrie and Robinson version, for all its difficulty, has become the standard version in English.

Heidegger spent his early years in a seminary but abandoned Catholicism in 1917-1918. His interest in and ambivalence toward religion permeates \"Being and Time.।" Heidegger was a friend of Edmund Husserl, the founder of the philosophical movement known as phenomenology. \"Being and Timel" is dedicated to Husserl and includes several laudatory references to him. Heidegger was Husserl's assistant at Freiburg, but he wrote \"Being and Timel" when he had assumed a position at Marburg. He became Heidegger's successor at Freiburg upon Husserl's retirement in 1928. Before writing \"Being and Timel", Heidegger was regarded as a brilliant scholar and a charismatic teacher. But he had published little. ।"Being and Timel" made him famous, virtually a celebrity, an accomplishment rare for a philosopher. Heidegger remained in the public eye through what became a notorious life through his political involvement with Nazism, and through a long life after WW II in which he did not expressly repudiate his earlier politics. 
Even though Heidegger turned Husserl on his head, the phenomenological influence in \"Being and Timel" is pervasive. Husserl's background in mathematical logic (and Heidegger's too in his early years) also plays more of a role in \"Being and Timel", I found, than I first thought when I read the book many years ago. In \"Being and Timel" Heidegger wrestles with many major philosophers, including Descartes, Aristotle, Kant, Kierkegaard, and Hegel, among others.

Even though Heidegger turned Husserl on his head, the phenomenological influence in \"Being and Timel" is pervasive. Husserl's background in mathematical logic (and Heidegger's too in his early years) also plays more of a role in \"Being and Timel", I found, than I first thought when I read the book many years ago. In \"Being and Timel" Heidegger wrestles with many major philosophers, including Descartes, Aristotle, Kant, Kierkegaard, and Hegel, among others.

Heidegger never completed \"Being and Timel" as he had originally conceived the work. The book as we have it consists of a long introduction, a section called Part I, titled $\backslash$ "The Interpretation of Dasein in Terms of Temporality, and the Explication of Time as the Transcendental Horizon for the Question of Being. " Part I has two large Divisions each consisting of many subchapters. The first Division, very simply, develops Heidegger's understanding of $\backslash$ "Dasein $\backslash "$ and of $\backslash " B e i n g-i n-t h e-W o r l d \backslash "$. The second, and much more emotively charged and difficult Division, deals with temporality, resoluteness, and death. Heidegger completed a third division of Part I, but rejected it as unsatisfactory and never published it. A projected part II of $\backslash$ "Being and Timel" never appeared, as Heidegger abandoned his original lengthy project for the book.

Being and Timel" is a book that requires substantial patience and concentration to read. The reader must be extraordinarily careful with Heidegger's definitions, as the author invents much of his own terminology and uses familiar terms in unusual ways. Beyond that, the style of the book is extraordinarily dense. Unsympathetic readers and critics find Heidegger willfully obscure. Some see the book as little more than gibberish. Obscure it is, but not gibberish. While portions of the writing seem to me to resist understanding, study will be rewarded. The form and style of the book are an integral part of Heidegger's teaching, as he encourages the reader to delve deeply into what might be regarded as simple, even trivial, matters and to see things that are close in a new light. The writing is heavily metaphorical with figures derived from theology and terminology that is suggestive of violence and sexuality in many places.

The book does not offer arguments in the sense of a traditional philosophical study. Rather Heidegger follows Husserl in trying to get the reader to see and to look at things afresh. Husserl studied ideals of consciousness while Heidegger turns his message to look at being through man's place in the world. There is a tension in the book, it seems to me, between seeing the world primordially, without the encrustations that have accrued from the Greek way of seeing things, and interpreting the world. Heidegger appears to do both.

Heidegger draws a distinction between ontics and ontology. Philosophers, scientists, and most lay people have thought only ontically -- about existing things. Heidegger wants to open up the question of being -- and draws what is a critically important distinction between existing things and reality -- which does not have the concept of thinghood. He attacks the Aristotelian concept of substance which is basic to much Western thought and the dualism of Descartes. Much of the book is an attempt to dissolve philosophical questions resulting from a substantialist metaphysics.

The book challenges the primacy most thinkers have accorded to the concept of reason and asks its readers to understand \"being-in-the-world $\backslash "$ and activity as the source of life from which subsequent concepts of reasoning arises. Although Heidegger had disdain for American philosophy, I found that a hard pragmatism underlies much of ।"Being and Timel".

In its concepts of historicity, commitment, the people, and perhaps in its derogation of reason, \"Being and Time।" could be read as laying a philosophical basis for the Nazism which Heidegger actively supported during the 1930s. This aspect of the work should not be minimized. But neither should the power, originality, and insight of $\backslash$ "Being and Timel" be denied.

His project here is to answer in a fundamental way what makes beings $\backslash$ "bel". To do so, he realized that he needs to ignore beings and in some way to go behind them and directly to the Being (i.e. that Being is not a being, but gives beings their Being). By questioning beings about their Being, one cannot go deeper. However, there is one being whose Being is to inquire into the meaning of Being - that is Dasein. Dasein is not the same as human being - but 
something that belongs to the human being. At the same time, Dasein was appropriated and is still in touch with the Being. In this book, Heidegger is questioning Dasein about its Being. All the talk about authenticity, guilt, anxiety, mood, care, death, others, and so on in this book is about recovering and experiencing this connection between Dasein and Being.

More concretely and as an example, beings are the fields of particular sciences (physics, history, logic, biology, theology, etc.). Heidegger wants to inquire into what makes possible such sciences and even to go below their foundations. By their nature, all sciences cannot inquire about their foundations and definitely cannot go beyond their foundations. This can be done only by fundamental ontology as done here. Because of this - the scientific, common, and traditional language is of no use here; on the contrary.

Because of its object (i.e. Being), this is \"fundamental ontology।". Because it inquires Dasein about its Being and since Dasein already has a pre-ontological understanding of Being, this is \"hermeneutics $\backslash "$. Because it goes to the things as they appear themselves, the method here is \"phenomenology $\backslash "$ as promoted by Husserl.

A being is any-thing that we talk about - a tree, God, a human, an idea, a hammer, an assumption, a theory, a unicorn, an electron, an expected event, a past event, a feeling, a number, and so on. For us moderns, the beings are equivalent with the real; and the real in turn is equivalent with extended substances. The medieval theologians, Descartes, and up to Kant - included res cogitans among beings and along with res extensa; and in this way their world of beings was richer when compared with our modern and materialistic one. However, by generalizing from beings to Being and by defining Being in terms of substance (as res extensa or/and res cogitans) or as ideas (as started with Plato) the entire western tradition fell into metaphysics.

According to Heidegger, the beings are of three types - Dasein-like, tool-like, and substance/presence-like. We discover them in this order. As we move from Dasein to tools and from tools to substances/presence, the beings are ।"poorer in Beingl", derivative, limited, and artificial. Sciences delimited and defined their objects of inquiries in the beings understood as present-at-hand (the third and most limited and artificial type of beings). Logic along with its truth followed as the proper method for this objective and restrictive ontology. This scientific and objective approach is ubiquitous today and well beyond its proper field. When we try to understand a tool as an object with properties we lose sight of what is essential in a tool. The further and even more serious error is to try to understand Dasein and Dasein-like beings (world, God, time, truth, history, and so on) as present-at-hand beings - like most of philosophies and sciences do these days (for example - human is a rational animal, or an input-output machine, or a biological system, or a spiritual substance, or a moral entity, or a subject, and so on). Actually, time is even more fundamental than Dasein and Dasein-like entities; in fact time makes possible Being - hence the title of the book ।"Being and Timel".

Truth understood as correspondence between a real object and a representation inside subject's mind, as certainty of a conviction/idea (a la Descartes or Husserl), as given by the transcendental categories within a subject as understood by Kant, as propositional truth understood by analytic philosophy, and so on - are all derivative and restrictive definitions of a more fundamental truth. This fundamental truth is the one given by Aletheia/ $\alpha \lambda \dot{\eta} \theta \varepsilon 1 \alpha$ as disclosure (i.e. think of Jesus who said $\backslash$ "I am the Truth $\backslash "$ as a perfect example of truth as Aletheia).

Since the project here is to rebuild everything on a more fundamental level; the old structures must be destroyed/ deconstructed. Any attachment to philosophy, science, logic, ontologies based on real/substances/extensions, systematic theology, and so on - stand in the reader's way of approaching and comprehending Heidegger. Some familiarity with Plato, Aristotle, Kant, and Nietzsche may help; but one must be ready to let them go as soon as he starts reading Heidegger. More helpful may be Kierkegaard, Meister Eckhart, St. Augustine, early Christians, and the pre-Socratics (assuming that one can read them in the original Greek). Reading books by different authors about Heidegger in order to understand Heidegger seems to me counterproductive and completely missing the point; one must just leap into Heidegger directly and have patience.

Looking for Nazi connections and hints in this book seems ridiculous to me. However, both Heidegger along with this book and the Nazi were produced by the same profound crisis (that included a rejection of democracy, traditional rationality, and ethics centered on the individual) and the need of fundamental renewal felt in Europe but especially in Germany - after the WW1; however, that is a completely different and controversial topic.

Philosophy indeed, it seems, is a road. The utterance means then: choose that philosophy and that road to wisdom in which you will not 'cut in two', in which you will propound, not contradictions, but firm and unchanging truths. Yet with the introduction of that scission dividing the ontic and the ontological, we find ourselves sitting at the very road cut in two we swore would be untouched. As the philosopher too concerned with the psychophysical, we begin and end with the wrong tools and placements of anything through which one cannot work out of. When Heidegger begins to enter 'in-the-world' we begin to see this as a precedent to ramble upon the endless infinite variations that prompt themselves to the physical — a Pollock painting of verbs serving no philosophical use. Through the obvious obfuscation only evident in the confused and the obscuring of Daoist origins do we finally understand the relevance 
of the entire deviation of authenticities and inauthenticities that permeates a portion of this book. That play of words that becomes the archonic instrument breathing dualisms finds itself losing its charm after every verb is a proverbial transmitting, charioteering, boomeranging (and so on) into new fractal amorphous verbs. The modalities are endless for all and Heidegger gets lost in the complexity while ultimately not doing metaphysics, but rather displacing common orderings of semantics. The case of the phenomenologist who identifies with his phenomenology. Though one may disagree with the book in its entirety, partially nod along or frown with foul intent, one must admire the beautific simplicity of Dasein, the self-reflexive meta-fictionalized Reader whose thoughts are splain in real-time and whose splaying is thought of in itself - though these \"places $\backslash "$ may not be of use. It's format certainly is. The book ends with an unfinished question mark. Or rather, a concretized question mark with no discernible answer since the Aletheia of such inquiry would result in absolute blissful theurgy.

What Heideggers tries to do, is creating an ontology of our Dasein within a phenomenological approach. The strenght of this is approach is that it does not make pre-assumptions about reality, but tries to view what is real in the way it reveals itself to us. Sein und Zeit is a taxonomy of our Being, revealing how we try to escape our loneliness and fear of death by fleeing into culture and others. As a (semi-)Buddhist I can relate to this.

Since Heidegger does not use external arguments for his theory, I can imagine scientists will have trouble accepting the things he does. Rationality, logics, etc. are not of primary value in his research. Heidegger reveals the structures of being primarily by finding the right words to describe our way of being-in-the-world. This makes certain paragraphs almost a sort of poetry, which I think was exactly Heideggers intention.

The question of being is not simple. The quotation from Sophist (244a) Heidegger inserts at the beginning of BT is worth citing:

For manifestly you have long been aware of what you mean when you use the expression 'being' ['on' in Greek which Heidegger translates as 'Seiend']. We, however, who used to think we understood it, have now become perplexed.

The distinction between an entity (ein Seiendes) and the being (das Sein) of that entity--the distinction that Heidegger insists on--is not easy. One mutates from the other and vice versa.

According to Husserl, the predicative judgments are made based on the copula 'is,' which (as the primal representative of all verbs) already indicates what Levinas calls $\backslash$ "the amphibology of being and entities।" (Otherwise Than Being or Beyond Essence (OB) 43). To say 'A is B' or 'the car drives nicely' is to express something about $\mathrm{A}$ or the car, which is immediately mixed with its attribute so described. What is visible in this sentence, however, is not the being of the entity but the entity with a certain attributes described in the predicate. Nonetheless, what is invisibly said also in the predication is the being of the entity that enables the predication in the first place. The verb 'is' (the primal verb of all verbs) enables the predication of the subject in the first place. The copula 'is' (or any other verbs) enables the seeing something 'as this' or 'as that.'

For Heidegger, however, such an illumination by the predicate or, as he puts it, \"the apophantical 'as' $\mid$ " (158) is made possible not in a theoretical judgment involving the couple 'is' (as in Husserl) but in dasein's involvement in the world --more specifically, in dasein's existence in the mode of care (Sorge), which is to be characterized as Angst--Angst about one's being stripped of all ontic concerns and ultimately about one's own most possibility of death, the possibility of the end of all possibility. Such an awareness or disclosure of (one's) being is possible only after dasein is awaken from its everyday absorption in the 'they' in its being-among-one-other [Unterinandersein] (SZ 128), where $\backslash "[t]$ hings are so because one says so $\backslash "$ (SZ 168), where no one owns up to anything. The being of beings, however, is disclosed in dasein's inauthentic mode of existence lost in the 'they' as well as in its authentic mode of existence characterized as care and ultimately in its ecstatic mode of temporality, wherein one's potentiality-for-being is affirming as one's having-been-ness of the past, i.e., in dasein's facticity, thrownness, or situatedness in which it finds itself always already. Ultimately, being is disclosed in its being-towards-death, the inevitable fate/possibility from which no one can substitute for another, the possibility of its impossibility, the possibility of its non-being. (The thesis about being as temporality, which is proposed in BT's table of contents but never worked out, cannot be fully understood unless one reads on to his later works, where, as discussed above, Heidegger changes his language and talks more about the 'objective' dimension of $\backslash$ "the happening of being $\backslash "$ to which humans play a receptive role as the $\backslash$ "shepherd of being $\backslash "$ or to which language plays the role of the $\backslash$ "house of being $\backslash$ " $(\backslash " . .$. essential thinking is presumably an event proper to being [ein Ereignis des Seins] $\backslash$ " (।"Postscript to 'What is Metaphysics?' $\backslash$ " in Pathmarks, 234)). The event character of being's move, the sending (schicken) of Being, will increasingly take on the form of historical destiny (geschichtlich Schicksal), where metaphysics is said to play out. Only by overcoming metaphysics, being in its essence can be disclosed, albeit briefly as in a flesh of lightning. 
resounds or [according to Heidegger] temporalizes in the verb to beand thereby becomes discourse and apophansis \" (OB) 39). Discourse reveals being (Sein). The 'said' (as Levinas puts it) remains on the level of being (Sein). ( $(" T i m e$ and the essence [Sein] that it unfolds by manifesting entities (identified in the themes of statements or narratives) resound as a silence without becoming themes themselves।" (OB 38).) Being is silently at work in the verb 'to be,' which is $\backslash$ "the verb par excellencel" (OB 42) enabling all predicative judgments, i.e., in the discourse or in 'the said.' ।"The verb to be in predication makes essence [Sein] resound, I" says Levinas more succinctly (OB 42). This observation enables Levinas to argue that 'the saying' is beyond 'the said' where being (Sein) resides, however silently or invisibly. And his project is to move beyond being (Sein). Saying (of the face of the Other) is beyond being that resides in the said.

My point, however at this junction at least, is that there is a $\backslash$ "mutation in the amphibology of being and entities [in logos or discourse]\" (OB 43) that \"perplexed।" not only the Eleatic Stranger in Plato's Sophist but also the keenest mind such as Heidegger, who devoted all of his philosophic life to the single inquiry, namely, the question of being. But did Heidegger truly overcome metaphysics that he criticizes as not fully uncovering the question of being in the first place? Was Heidegger able to un-do or 'destroy' what Derrida termed \"the metaphysics of presencel" in the latter's reference to Husserl in Speech and Phenomena and Other Essays on Husserl's Theory of Signs? That is, did not Heidegger still fall within the sway of being even in the later years, despite his crossing out the word 'being'? Levinas says: \"... being is never ... its own reason for being. $\mid "$ Is Heidegger's inquiry sufficiently deep enough? What grounds or justifies being? To say that being is grounded in abyss or on nothingness, as Heidegger does in The Principle of Reason, is to take a metaphysical posture and to believe in the mystery of cause sui (the self caused cause--the very first principle of metaphysics). To overcome metaphysics is still to remain within metaphysics; not to philosophize is still to philosophize. But one can do better than philosophy. 